\title{
Globalization of Constitutional Law through Interaction of Judges
}

\author{
By Jutta Limbach, Berlin / Munich*
}

\section{Creation of Networks between Decision-makers}

During the last decades, governments, lawmakers and judges have been faced with a multitude of challenges transcending national borders. Let me just mention three factors contributing to this situation:

- The globalisation of trade: Whenever companies wish to export or invest abroad, lawyers are called upon to examine the applicable rules.

- The development of an international and, in particular, European conception of Human Rights: The application and interpretation of the European Convention of Human Rights, which is binding on 47 European States, raise similar questions throughout Europe.

- People's freedom of movement: The increased mobility within Europe and all over the world necessitates the creation of a common set of rules on how to deal with complex issues, for example concerning family law or the law of extradition.

These challenges call for effective ways of enforcing the already existing structures of international co-operation and of creating novel approaches.

One of these approaches is the creation of networks between decision-makers on an international level. Anne-Marie Slaughter describes the evolution of "a new world order" through a multitude of more or less formal networks between law-makers, administrative bodies and judges from different countries. They may connect national bodies and their foreign counterparts in a horizontal way, aimed at the exchange of information and mutual support, or they may connect international institutions and their national interlocutors in a vertical way with a view of enforcing international standards. These networks are not intended to replace, but to supplement the existing governmental structures. They are less concerned with issues of hierarchy, but with means of improving co-operation on a transnational and supranational level. Instead of the classic instruments of coercion, they use the "soft powers" of information, socialization, persuasion and discussion - they are "powerful through attraction rather than coercion". 1

* Prof. Dr. jur., President of the Goethe-Institut, 1972-1989 Professor at the law faculty of the Free University, Berlin; 1989-1994 Member of the Berlin Government; 1994-2002 President of the Federal Constitutional Court, Karlsruhe; con-founder of the German Association for the Sociology of Law. E-mail: Galic@ goethe.de

1 Anne-Marie Slaughter, A new world order, Princeton University Press 2004, pp. $5,27$. 


\section{Co-operation of Judges}

Recent years have seen the emergence of a proliferation of international gatherings of judges. Allow me to mention just three of them:

1. In 2004 the Presidents of the Supreme Judicial Court of the European Union founded their own network. This Network has the declared aim to give European Institutions an opportunity to request the opinions of Supreme Courts and to bring them closer by encouraging discussion and the exchange of ideas. In the terms set out above, this association may be described as a horizontal network which aims both at exchanging know-how at an internal level and at spreading information through external channels, in particular by corresponding with European institutions. The members gather for colloquiums to discuss matters of common interest. Last year's conference, for example, focused on issues relating to the institution of Supreme Courts, such as budgetary questions, the methods of appointment of judges and disciplinary proceedings against judges. The founding members have also set up a website ${ }^{2}$ aimed at the constant exchange of information.

2. The European Court of Human Rights dedicated the conference at the occasion of the opening of the judicial year 2005 to a dialogue between judges of different national and European courts. The conference was aimed at further smoothing the co-operation between the courts and thus to strengthen the impact of the European case-law on the decisions taken by the national court. As the European Court of Human Rights functions as a last instance in all question relating to the rights guaranteed by the European Convention on Human Rights, this may be viewed as an example for a vertical dialogue between an international court and its national counterparts.

One of the main concerns put forward by the national courts during this conference was the issue of subsidiarity, in particular the question if and to what extent the Strasbourg Court was competent to control the application of the domestic law by the domestic courts. While readily accepting the international court's supremacy regarding the interpretation of the Convention, one of the guest speakers considered that the "loss of sovereignty (is) less readily accepted in ... cases in which the European Court interprets the factual elements necessary for the application of concepts of pure domestic law differently from the domestic courts.",

3. Let me now draw your attention to a network of judges I am more thoroughly familiar with, having had the benefit of participating in several of its events:

The emerged from a meeting held in Dubrovnik in 1972 between the Yugoslav, Italian, Austrian and German Constitutional Courts. While the number of participants increased over the following decades - the Conference currently counts 39 members from as many

2 3

www.rpsjue.org

Guy Canivet, National supreme courts and the European Convention on Human Rights: New role or radical change in the domestic legal order? in: Dialogue between judges, European Court of Human Rights, Council of Europe, 2005, p. 19 s., p. 30. 
European countries - the structures remained basically the same. It was not until 1999 that the conference decided to give itself a statute. Notwithstanding, the conference remained a rather informal gathering. The Conference of European Constitutional Courts does neither have a legal status nor a permanent secretariat. It does not take any binding decisions other than those related to the organisation of its conferences. In between its meetings, which take place once every three years, it basically exists as an idea in the heads of the members of the relevant Constitutional Courts ${ }^{4}$.

The primary aim of the Conference, as set out in its statute, is "to promote the exchange of information on the working methods and case-law of its member courts together with the exchange of opinions on institutional, structural and operational issues as regards public law and constitutional jurisdiction".

The topics to be discussed during the conference are chosen during a preparatory meeting by the "Circle of Presidents" which comprises the Presidents of its member courts. For the tenth conference, which took place in Budapest in 1996, to pick just one example, the Circle of Presidents chose two topics: "Freedom of expression in the jurisprudence of constitutional courts with special regard to regulations on the electronic media" and "Separation of powers regarding the constitutional court's jurisdiction”.

These examples illustrate the two areas from which topics are generally chosen, namely, the case-law on the application of individual constitutional rights on one hand and the discussion of structural issues on the other. The topic relating to freedom of expression was of a specific transnational interest, since media, in particular in their electronic version, naturally do not stop at national borders.

In preparation of the meeting, the participating courts filled out questionnaires relating to the two chosen topics. Members of the Hungarian Constitutional Court, being the hosts, prepared two general reports which accumulated the information submitted by the members and served as a basis for the ensuing discussions.

As such, the Conference of European Constitutional Courts does not have any coercive power - and it does not strive to obtain it. It can be characterised as a horizontal information network enabling constitutional judges to entertain personal contacts and to exchange know-how and experience.

While these objectives might appear to be rather modest, the impact of the Conference should not be underestimated. Its deliberations allow a very open and intensive dialogue on fundamental issues of constitutional law and on methods of interpretation based on mutual respect and appreciation. The different legal and cultural backgrounds of the participating judges allow enlightening problems from a broad comparative perspective. The majority of the participants being active constitutional judges, the fruits of these discussions are very schen Verfassungsgerichte, in: Festschrift für Wolfgang Zeidler, Berlin, New York 1987, p. 315 et s. (p. 341). 
likely to find their way into the case-law of their respective courts ${ }^{5}$. I do admit that it may be difficult to prove the effects of this "cross-fertilization" (Anne-Marie Slaughter), as many constitutional courts remain reluctant expressly to cite the case-law of their international counterparts. Nevertheless, the Conference of European Constitutional Courts actively promotes the development of a common "language" of European constitutional culture, or at least a grammar thereof, that is to say, its methods and standards. ${ }^{6}$

\section{Human Rights Protection in the Council of Europe Framework}

Last but not least let me draw the attention to the human rights protection in the Council of Europe framework. The European Convention on Human Rights and the European Court of Human Rights play an eminent role in safeguarding democratic values across Europe, as well as in setting an example even beyond the borders of its member states. The Enlargement of the Council of Europe and the accession of the central and east European democracies have contributed to stability in the whole Europe. The right of individual application is the most distinctive feature of the control mechanism. The Court is the only international court to which any individual, non-governmental organisation or group of individuals have access for the purpose of enforcing their rights under the Convention. Beyond this individual supervision the Court has the constitutional mission to lay down common principles and standards relating to human rights and to determine the minimum level of protection which a state must observe.

The exponential increase in the number of individual applications is now seriously threatening the survival of the machinery of the judicial protection of human rights. There is a fundamental conflict between the size of the population who have access to the Court and the Court's responsibility as the final arbiter in human rights matters for so many different states. No other international court is confronted with a workload of such magnitude while having at the same time such a demanding responsibility for setting the standards of conduct required to comply with the Convention. Because the system is in danger of collapsing the Heads of State and Government of the Council of Europe set up a Group of Wise Persons to consider the long-term effectiveness of the ECHR control mechanism. This Group recommends measures to remedy this situation, but did not follow the idea of giving the Court a discretionary power analogous to the certiorari procedure of the US Supreme Court, because this authority would be alien to the philosophy of the European human rights protection system. The right of individual application is a key component of the control mechanism of the Convention. ${ }^{7}$

5

Zierlein, op. cit., p. 335.

6 Lázló Sólyom, On the Co-operation of Constitutional Courts, General reports of the 10th Conference of the European Constitutional Courts, Budapest 1996, p. 4.

7 
The Group proposed besides other measures the establishment of a new filtering mechanism. Here is not the place to give details to and to discuss the proposals. But in its entirety the Report is characterized by the variety of its proposals. The recommendations of the Report are addressed at many institutions, such as national courts, and at non-state entities, such as professional organisations, and last but not least at the civil society which plays a significant part in human rights protection, which is important to maintain and expand. The multitude and the variety of the addressees demonstrate the difficulty of an international institution as the European Court of Human Rights to establish a supporting network in a globalized world. 